\title{
Alarm sounded for lack of bringing and building crystallography in Ethiopia
}

\author{
Alebel N.Belay \\ Department of Chemistry, Bahir Dar University, P.O.Box 79, Bahir Dar, Ethiopia \\ crossispower@gmail.comoralebel.nibret@bdu.edu.et
}

As you know the current population of Africa is 1,374,451,375 as of Monday, July 26, 2021, based on the latest United Nations estimates. Africa population is equivalent to $16.72 \%$ of the total world population. Africa ranks number two among regions of the world (roughly equivalent to "continents"), ordered by population. With over 110 million inhabitants, Ethiopia is one of the most populous landlocked countries in the world, as well as the second-most populous nation on the African continent after Nigeria.

Bahir Dar University is now among the largest universities in the Federal Democratic Republic of Ethiopia, with more than 52,830 students in its 219 academic programs; 69 undergraduate, 118 masters, and $32 \mathrm{PhD}$ programs. The vision of Bahir Dar University is to become one of the ten premier research universities in Africa by 2025. For instance, basic and in-depth skill and knowledge in introduction to Crystallography, Crystal Chemistry, Chemical crystallography, etc., and most favoured technique for structure determination of proteins and biological macromolecules for undergraduate and postgraduate students will be compulsory in future. Currently, BDU students' and the rest part of Ethiopia still have had many challenges to start the extensive practical classes in crystallography using equipment like Single-crystal X-ray diffraction. Because of problems associated with potential future Ethiopian Crystallographic Association (EthCA) and working it for most advanced technology and many other emerging applications are evident $[1,2]$. Indeed, a senior scientist helping young scientists to achieve their potential is important but it is often difficult to establish exactly when a scientific multidiscipline began. This is also true when trying to identify the moment when a particular field of research got a foothold in a new geographical region like Ethiopia.

Therefore, the main goal of this presentation is too aware and build knowledge, scientific research work and acquire experience to promote science through crystallography as a vehicle further in Ethiopia (my home country, Bahir Dar University, Ethiopia), A frica and beyond. Due to this we are trying to continue the thrust to establish a Steering Committee for a potential future establishment of an Ethiopian Crystallographic Association (EthCA). Moreover, experiences I got from different conference start with IUCr2014 in Bloemfontein, South Africa, the PCCr1 meeting in Dschang, Cameroon, in 2016, IUCr meeting in Hyderabad, India, in 2017 and so on were helped us to achieve our objective [2-5]. But the African Crystallographic Association's (AfCA) 2017 report shown to pursue a follow-up meeting of all potential members of the AfCA Steering Committee, or representatives, to determine further actions for the immediate future, but still nothing to do it and not seen any on-going progress practically regarding to help establishing crystallography in Ethiopian. This might be effect of lack of close communications and COVID-19 in financial crises.

[1] Belay, A.; Yadav, O.; Taddesse, A.; Diaz, I. Bull. Chem. Soc. Ethiop. 2015, 29(2), 247-258.

[2] Belay, A.; Koen, R.; Venter, J.; Drust, R. Z.kristallogr.NCS. 2016, 231(2), 513-515.

[3] Belay, A.; Venter, J.; Roodt, A. Z.kristallogr. NCS. 2017, 232(2), 163-164.

[4] Belay, A.; Venter, J.; Roodt, A. Acta Cryst. (2017), A73, C1163.

[5] Belay, A.; Venter, J.; Alexander, O. Eur. J. Chem. 2020, 11(3), 255-260.

Keywords: Challenges; crystallography; Establishing, Young scientist, Ethiopia

My thanks and appreciation go to the following institution for supporting me: Crystallographic team of the University of the Free State for the PhD training and fund supported by South Africa's National research Foundation (NRF) and the World Academy of Science (TWAS) (UIDs 99782). And also UFS, BDU, UNESCO and IUCr for travel grants of various international conferences (real and virtual) since 2014 to present. 